\title{
UDK: 338.1
}

DOI: https://doi.org/10.26661/hst-2020-4-81-12

\section{THE IMPACT OF DIGITALIZATION AND GADGETIZATION ON THE DEVELOPMENT OF CORPORATE SOCIAL RESPONSIBILITY IN THE EVOLUTION CONDITIONS FROM GLOBALIZATION TO REGIONALIZATION}

\section{(C) HANTSOVSKYI, OLEKSII}

Engineering educational and scientific Institute of Zaporizhzhia National University (Zaporizhzhia, Ukraine)

\section{E-mail: teck-t@yandex.ua,}

ORCID iD: https://orcid.org/0000-0002-3418-7550

Інженерний навчально-науковий інститут Запорізький національний університет, пр.Соборний, 226, 69006 Запоріжжя, Украӥна

Engineering educational and scientific Institute of Zaporizhzhia National University, 226 Soborny Avenue, 69006 Zaporizhzhia, Ukraine

\begin{abstract}
The article highlights the essence of the concept of corporate social responsibility (CSR) in the context of the development of global trends of the modern world, which has the development of the Fourth Industrial Revolution and the transformation of global trends from unification integration processes into diversified structural directions. The necessity of implementing the principles of regionalization and local protectionism is compared with the innovative need to integrate with the concepts of gadgetization and digitalization in the current state of the modern world. The correlation of corporate social responsibility in the market with transformational changes in the world in the current crisis was investigated and focused on the features of the principles of CSR formation in modern global business trends, among which they were categorically and conceptually analyzed. The unique convention of the formation of the concept of corporate social responsibility based on the principles of regionalization and local protectionism is considered and disclosed. The results of the study show that the focus on the development of only technologies is limited. But the importance of disclosing the impact of technology on the welfare of people, world progress, expanding the capabilities of science and man, the introduction of the concept of corporate social responsibility with its principles and norms, at all levels of management will ensure the implementation of common, flexible forms of management, interaction with new technologies of the Fourth Industrial Revolution 4.0, with the understanding of breakthroughs in digital technologies and adaptation to their effects.
\end{abstract}

Keywords: corporate social responsibility, gadgetization, digitalization, regionalization, globalization, fourth industrial revolution.

Introduction. The relevance of the study of the topic of forming the concept of corporate social responsibility in the context of the present development of global trends is determined by the scope of the Fourth Industrial Revolution and global trends that contribute to the unfolding of transformations caused by the present technological shifts. Globalization refers to all those processes in which the peoples of the world are involved in a single global society. These processes are triggered

The impact of digitalization and gadgetization on the development of corporate social responsibility in the evolution conditions from globalization to regionalization 
by economic internationalization and the spread of capitalist market relations [30]. They are generated by global production, which is being defined by global finances and is evolving in the context of global history. Among many different tasks we face today, the most powerful and important is the need to understand the conditions of formation and the essence of the concept of corporate social responsibility in the context of the development of global trends of today. These changes lead to the transformation of humanity, so we must learn to manage them, as we are in the process of a revolution that is radically changing the course of our daily lives, ways of working and interaction that require the formation of corporate social responsibility and enhancing the culture of management [1].

Setting objectives. Globalization and technological change are so powerful that they make our day both the most promising and at the same time full of the greatest potential threats in human history. Our fears are primarily due to the fact that people empowered to make decisions are often trapped in a linear way of thinking, incapable of strategically forward thinking about the revolutionary changes and innovative decisions that shape our future. The object of this research is the development of corporate social responsibility as a social and economic phenomenon [32]. The subject of the rescarch is the impact of digitalization and gadgetization on the development of corporate social responsibility in the face of evolution from globalization to regionalization. Moreover, globalization is based on the digital revolution and numerous technologies that lead to unprecedented powerful paradigm shifts in the economy and governance that require the formation of the concept of corporate social responsibility [2].

\section{Summary of the main results.}

The development of the concept of corporate social responsibility as a component of the management culture in the current economic environment requires the transformation of classic management models. A common factor in concept formation is the set of methods, principles, foundational ideas that relate to staff, their work discipline, legitimacy, and effective execution. Using modern approaches to the formation of the concept of human resources, researchers note that organization in its development focuses on highly qualified staff, continuous integration with the development of production, supporting the principles of delegation, flexibility, partnership [29].

We are considering the principles of corporate social responsibility development in the context of a management culture and the overall human resource impact of globalization. Let us examine in detail the essence of globalization processes, which act as a combination of humanity in a structurally-functional system, which acts as an organized integrity, functioning on universal principles. The main problem of forming the concept of corporate social responsibility in the context of 
the management culture is the ethnomental constituents, spiritual and national values, which imprint the global trends of the present. So let's take a deeper look at the thinking of scientists about the process of globalization [28].

Global modern international trends unfolded at the beginning of the XXI century. Globalization is defined as the worldwide process of interaction between economic, political and socio-cultural processes, their integration and unification. The main purpose of globalization was to diride labor, to have freedom of choice and opinion, to integrate and understand different religious, ethnic and cultural backgrounds. The subject of globalization processes is the development of transport and logistics, information progress, the development of mobile communications, the Internet $[4, \mathrm{p}$. 706]. The process of globalization is the reorganization of production capacities the territory, the development of financial and investment markets through the expansion of national borders, labor markets, international technologies and communications, as well as the cultural component [3].

Global trends in modernity and informatization have led to openness and publicity of business, where each entity can obtain the necessary information through online sources. Publicity in the Internet has emerged as a popular form of business that includes a large pool of potential customers who receive the necessary information through the network.
Partners,

competitors,

all interconnected parties of the global whole can have access to the information about the company, product, service, etc. Thus, the activity of users on the Internet is the competitive advantage of progressive enterprises in the face of today's global trends. For example, article publishing, video reviews, and blogging have emerged as effective marketing tools [4].

However, the ineffectiveness of globalization was revealed in 2020 , when the worldwide viral quarantine was proclaimed in progressive countries around the world and among the leading countries as a global problem of today. State borders, enterprises, corporations were closed, most of the enterprises that were operating with a great deal of integration into external conditions were discontinued [27]. Marketing demand has changed the course and business partnerships have failed. In the short term, globalization processes have been transformed into regionalization processes and replaced by local protectionism. The global health crisis, affecting most of the world, has indirectly led to an escalation of the financial and economic crisis. In the difficult global situation on the world markets, experts say that the processes of globalization are suffering recession, reducing consumer demand, stopping social and economic activity of the population, which in the course of globalized events are suffering from the quarantine world events, among 
which can be noted the cancellation of world international sports, business and display campaigns [5].

The formation of the concept of corporate social responsibility in the context of the present development of global tendencies requires the analysis of new world trends, such as "regionalization" and "local protectionism". The importance of the latter is very acute in the local markets and economies of the states, because only internal economic interactions develop, and for the larger part of small and medium-sized businesses, the processes have moved to a remote distance level, among which are the emerging tendencies of the globalized world - "gadgetization" and "digitalization".

To begin with, let us analyze the notion of "regionalization", which is defined as counteracting globalization, and the local need for effective use of the local factors [6].

In recent decades, the need for regionalization has gained significant prominence in 2020 with the closure of borders and international markets for most businesses in the world [26].

The principles of regionalization that need to be assessed and considered are as follows. First, by the main principle of regionalization is to strengthen the position of a particular local entity in the context of globalized processes. Secondly, a detailed analysis of the internal markets and the search for opportunities to implement formalized strategies are needed wit is necessary to investigate. Thirdly, the vector of realization and formation of strategic projects involving the strengths of the enterprise to minimize the weaknesses of the internal environment (not only the internal state of the enterprise, but also the internal markets of the state, regions). We transform these principles of regionalization into stages of business activity implementation in the context of regionalization (see diagram 1.1).

Therefore, a step-by-step outlined by the authors, in accordance with to their own observations, makes it possible to the definetion the vector of sustainable development of enterprises that appeared in the situation of information stochasticity, instability, uncertainty [25].

We distinguish general tendencies that the concept of corporate social responsibility is undergoing. They are commercial involvement, low public awareness of an adequate understanding of corporate social responsibility, identification and resolution of stakeholders problems [4]. The contemporary convergence of CSR and society, which is getting to transform the conception, has been determined by the factors that encompass social activity. The factors are: ethical behavior, environmental protection, transparency of activity; as well as indirect solutions to social inequalities, community outreach and partnerships [7].

In order to effectively implement the concept of corporate social responsibility in the context of the development of global trends today, it is necessary to use the analysis of such terms as "gadgetization" and "digitalization" [20]. 


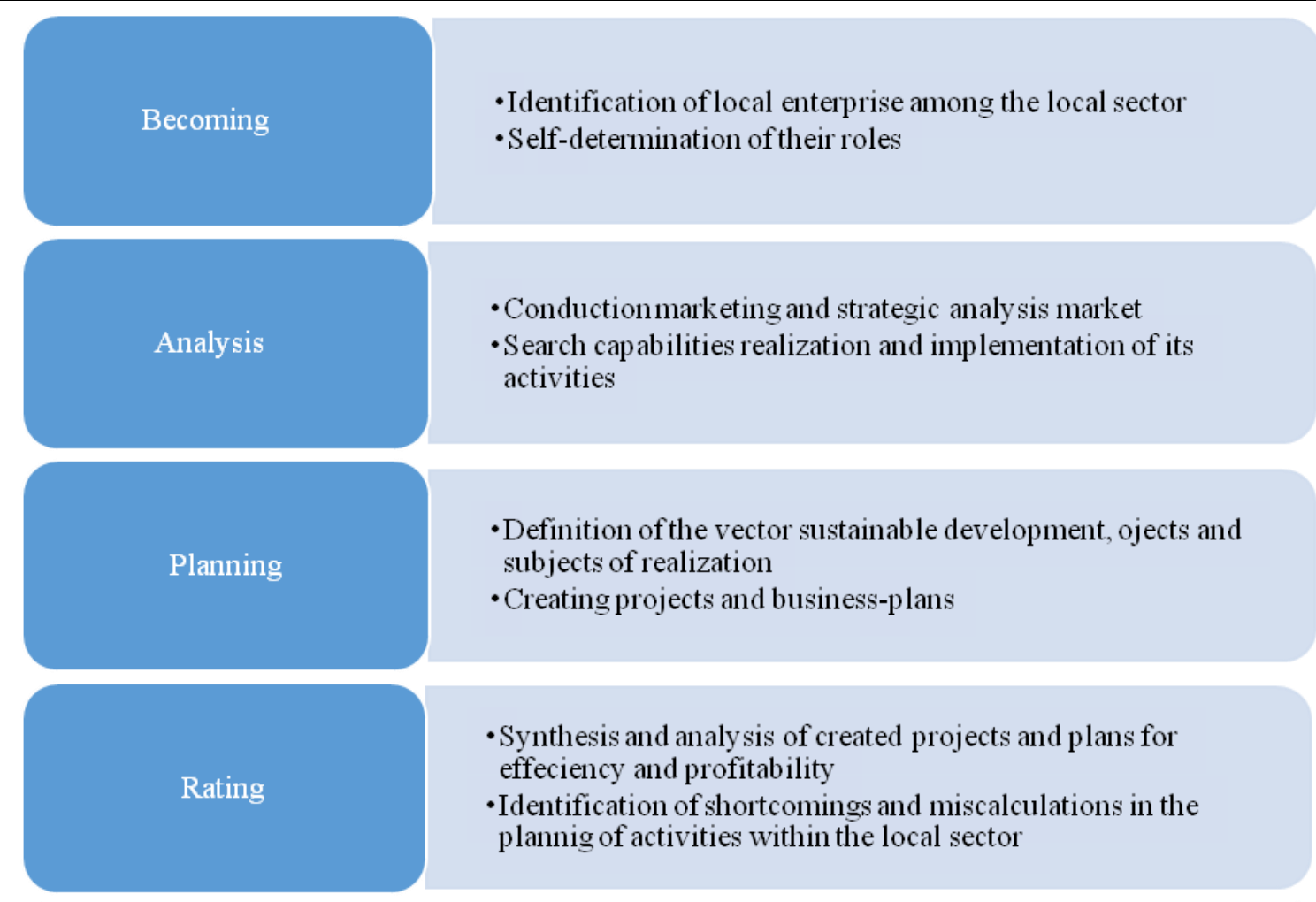

\section{Realization}

Diagram 1.1 Stages of implementation of the regionalization principles for business activities

(Source: own study)

Gadgetization is the concept of using and introducing technological progress, not only in everyday life, but also in the scientific, economic, social sectors of human life. It is gadgetization that has a great deal of influence on the entire global apparatus of the world, creating thus the possibility of multifaceted and close interaction of the modern world, as well as the fact that some technologies give birth to new, even more powerful ones [8].

This factor is based on the digital revolution and numerous technologies that lead to unprecedented, powerful changes in the paradigms of economics, management, business, which require the further development of the concept of gadgetization in the world. For example, most online stores, salons, manufacturers, and government agencies have their own platform in the context of gadgetization [9].

There are elements that, according to the authors, effectively function as components of gadgetization, including: site, online store, mobile application, call center, work pages on social networks, video reviews and press releases, as well as other initiatives of innovative technologies which are updated daily. For example, a Ukrainian EMM mattress company has developed its own free-to-use platform for smartphones and computers [24]. The application allows you to receive timely news about current promotions, discounts,

The impact of digitalization and gadgetization on the development of corporate social responsibility in the evolution conditions from globalization to regionalization 
special conditions. The user-friendly interface gives access to an assortment of all products and price lists. The company has a website on the Internet, its own brand pages on social networks. The presence of the Call Center allows you to conduct social feedback with consumers, answer questions and analyze examples. It also allous to disseminate information about what products the company produces, advertizing them in its own "EMM Magazine" branded magazines, which currently have 14 issues. Finished products and branded packaging have a QR code, attached to each mattress, which allows smartphone users to easily get more information in no time [10].

According to this analysis, digitalization is the introduction of digital technologies in all spheres of human life - from domestic needs to industrial capacity. Digital transformation is the transformation of an organization's existing analog products, processes and business models, which underlies the effective use of digital technology. Digital technologies include: the Internet, robotics, cyber systems, artificial intelligence, paperless technologies, additive technologies, mobile technologies, biometrics, quantum technologies, etc. [11].

According to Ukrainian law, the term "digitization" is defined as providing the physical world with electronic-digital devices, tools, systems and the establishing electronic-communication exchange between them, which in fact allows for the integrated interaction of virtual and physical spaces [7, p. 67].
Digitalization requires enterprises to create a corporate information system that ensures timely information flow between the partner enterprise - the consumer on the principles of timeliness and objectivity. Such a principle of the web must always have the ultimate recipient of information, that should guide their promotion to the public good, using information processes and routes. Integration of digitalization in business is the newest principle of competitiveness through the implementation of modern information and digital technologies in products, services and tools of implementation.

Cybernetics founder Norbert Wiener has identified that digitalization is the embodiment of modern cybernetics, management science, automation, and living organisms [12]. Digitalization is the basis for gadgetization, because information processes consist of digital data, which are further developed as a tool for enterprise competitiveness. For example, thanks to the development of digitalization that the Internet, as well as Internet marketing, websites, social networks and innovative multi-stakeholders collaboration tools have become popular. In its turn, the deployment of corporate social responsibility in a globalized environment is widespread on official websites and enterprise pages, without which public access, information on objects and entities of the enterprise becomes more difficult, and in some cases impossible, which minimizes the full effect of corporate social activity [13]. 
The use of corporate social responsibility strategies in the context of the modern challenge of regionalization and gadgetization is possible under the condition of implementation of potentially necessary information on internal corporate regional networks, local groups, environmental projects of the area, expansion of the implementation of important social issues, making immediate difficult decisions in the context of informational utility [14].

Here is an example of the world experience of countries in difficult times for business and entrepreneurs when most were quarantined by the COVID-19 virus outbreak. For example, most U.S. businesses have incurred high costs of withholding profits for workers without timely government subsidies. And by experts, a historical example of using corporate social responsibility by Johnson \& Johnson was cited. It happened when in the early 1980s, with the fatal accident of 7 people in Chicago while taking drugs of their production. It was decided to eliminate from the implementation process worldwide, the entire assortment of poisonous products in order to avoid further casualties on the part of consumers, despite the high economic costs [15]. The decision was made relevant, timely, morally and socially oriented, which can be categorically attributed to the real social responsibility of the enterprise [16].

Therefore, the principle of corporate social responsibility, which lies in the theoretical basis, proceeds from the fact that it should be aimed at the namely the society, stakeholders, consumers, staff, which will maximize the effectiveness of CSR activities. Here are the principles of corporate social responsibility [17]. The first (priority) principle is to provide conditions for employees and workers, to protect labor and to ensure safe working conditions. The second principle is to provide flexible conditions for the realization of their business functions: to have creative business freedom, together with personal responsibility. The third principle is the mandatory feedback: with staff, consumers, partners, society, authorities, which means the importance of hearing and using the feedback and wishes of feedback as one of the tools to improve position and efficiency. The fourth principle is publicity, openness and timeliness in informing clients, partners and other participants of interaction about the functioning of business in difficult times, the use of projects and strategies, which improves the results of social activity [18].

The principles of Corporate Social Responsibility strategies in the digital age should be correlated with the components of the CSR concept, as the multidimensionality of knowledge has been revealed in the context of globalization, and the challenge of today is the need to evolve concepts from globalization to regionalization and localization. The restructuring of the concept of corporate social responsibility into components was divided as follows: 1) social; 2) environmental; 3) human; 4) cultural 
[19]. We make the relation in the form

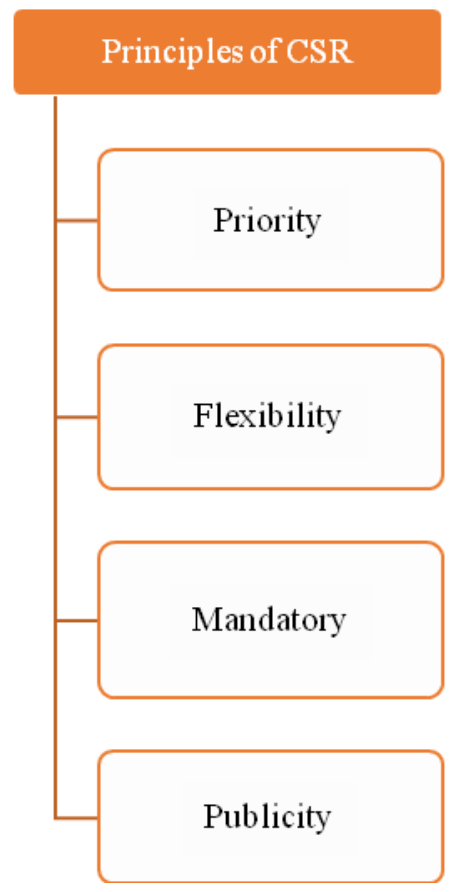

of a block diagram (see Fig. 1.1).

\section{Components of CSR}

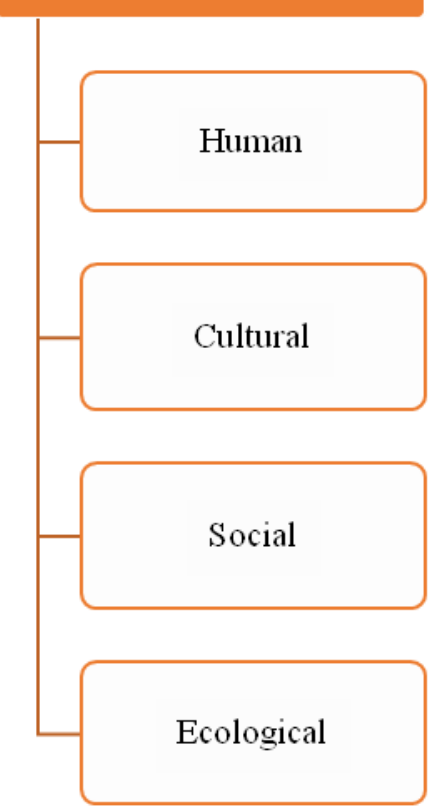

Figure 1.1 Ratio of principles to CSR components

(Source: own study)

Therefore, it can be noted that in a difficult economic environment for business, it is necessary to make prompt decisions, and each of the principles falls as the main element in the activities of the concept of corporate social responsibility. We give a description of each of them in a structured form of a table (see table. 1.1).

Table 1.1 Correlation of principles and elements of corporate social responsibility (CSR)

\begin{tabular}{|c|c|c|}
\hline & Principle - Element & Feature \\
\hline & "Priority is human" & $\begin{array}{c}\text { the main component of business is human resource, which is an } \\
\text { important indication of the decent provision of people in the course } \\
\text { of successful business activity, a priority component of which is } \\
\text { human activity }\end{array}$ \\
\hline "Flexibility is Cultural" & $\begin{array}{c}\text { the ability to adapt to change, to maneuver, including creativity } \\
\text { of search and creativity that promotes cultural development }\end{array}$ \\
"Responsibility is social" & $\begin{array}{c}\text { attention to social topics, complex issues and issues of society, } \\
\text { which is an integral part of every sustainable enterprise }\end{array}$ \\
\hline friendly" & $\begin{array}{c}\text { the scope of corporate social responsibility in the context of } \\
\text { interaction with the environment includes the right public approach, } \\
\text { competent PR management, which will lead to the efficiency and } \\
\text { sustainable development of both society and people }\end{array}$ \\
\hline
\end{tabular}

(Source: own study)

Thus, despite the importance of each of the principles and their components, in the context of the digitalization and informatization of the world, the development of "publicity" is the main need of the enterprise, including the right public approach, competent PR management, which will lead to efficiency and sustainable development both a 
society, and human groups. In implementing each area of activity of the CRS components, it is necessary to obtain a certain level of information in order to overcome information stochasticity, and to move to a specific implementation of the strategy, to achieve a decent level of efficiency of both human and society groups through the introduction of corporate social responsibility. Gadgetization allows to establish a decent level of informing consumers and the population as a whole about the necessary strategic actions of the company through media, digital technologies. For example, conducting classic email marketing, allows you to move to an innovative level through the use of gadgets, mobile applications (such as Viber, WhatsApp, Telegram) [20].

Conclusions. Thus, the impact of digitalization and gadgetization on the development of corporate social responsibility in the face of evolution from globalization to regionalization shows that the role of corporate social responsibility is increasing, as exemplified by the facts of the coronavirus pandemic. It is tempting to focus on the development of technology alone; however in fact, the impact of technology on human wellbeing, the development of science for the benefit of man, progress, and empowerment of science and man are more important [21]. Corporate Social Responsibility in an evolving environment from globalization to regionalization is a value that must protect the progress of society, promote the capacity of science and human freedom, and be used for the benefit - from initial idea to development and application. The impact of digitalization and gadgetization on the development of corporate social responsibility in the evolution from globalization to regionalization has shown that CSR can increase public well-being, life expectancy, economic and physical security, and open up new opportunities for useful and exciting activities in a sustainable environmental environment [22]. As before, leaders will have to cope with the uncertainty generated by rapid technological change in the new conditions of global development, but it is far more important to change the way of thinking, taking into account the effects of the system level, while maintaining a focus on the future and on the shared values of different stakeholders. Rules, norms and structures for a number of powerful new technologies are already being developed and implemented around the world, so it is time for the introduction of corporate social responsibility at all levels as a determinant of shared values [23]. It is enabling not only the creation of a new technology project but also more flexible forms of management and positive values that fundamentally change the way we live, work and treat each other; the need to cultivate fundamental skills in adapting to the fast-changing world, the technologies of the Fourth Industrial Revolution 4.0, understanding the breakthroughs in digital technologies and adapting to their breakthrough influences. 


\section{Список використаних джерел}

1. Ажажа М.А., 2012. Моніторинг як інструмент забезпечення якості державних та муніципальних послуг. Гуманітарний вісник Запорізької державної інженерної академії. 50. 270-277.

2. Ажажа М.А., 2006. Теоретико-медологічні засади концепції людського капіталу. Ефективність сучасного менеджменту організації: зб. наук. праць. Х.: ХІМБ. 267-271.

3. Regina Andriukaitienè, Valentyna Voronkova, Olga Kyvliuk, Marina Maksimenyuk, Aita Sakun, 2017. Theoretical insights into expression of leadership competencies in the process of management. Problems and Perspectives in Management. 15 (1-1). 220-226.

4. Каппель, О. Л., 2004. Глобалізація. Українська дипломатична енциклопедія. Київ. 706.

5. Воронкова, В. Г., 2008. Глобалізація як процес універсалізації стосунків між державою та ринком. Гуманітарний вісник Запорізької державної інженерної академії. Запоріжжя: РВВ ЗДІА. 35. 15-35.

6. Винск, Б., 2020. JPMorgam офіційно прогнозує, що до липня США та Свропу погіршать спад, спричинений коронавірусом. Доступно за посиланням: https://markets.businessinsider.com/news/stocks/coronavirus-fuel-recession-forecast-useurope-economic-july-market-jpmorgan-2020-3-1028994637/ (звернення 16 Квітня 2020).

7. Andriukaitienė R., Žukauskas, P., Vveinhardt, J. (2018). Management Culture and Corporate Social Responsibility. London: Intech Open. 66-67.

8. Фішук, В., Матушко, В., Чернев, Е. та ін., 2018. Україна 2030 - країна 3 розвинутої цифрової економіки. Доступно за посиланням: https://strategy.uifuture.org/kraina-z-rozvinutoyu-cifrovoyu-ekonomikoyu.html (звернення 16 April 2020).

9. Петров, А., Іванін, А., 2017. Спасение в цифре. Оцифровка - главный фронт мировой конкуренции». Доступно за посиланням: https://finval.ru/about/articles/spaseniev-tsifre-tsifrovizatsiya-osnovnoy-front-mirovoy-konkurentsii-/ (звернення 16 April 2020).

10. Крамер, М., 2020. Коронавірус випробовує корпоративну соціальну відповідальність. Доступно за посиланням: https://hbr.org/2020/04/coronavirus-is-puttingcorporate-social-responsibility-to-the-test (звернення 16 April 2020).

11. Ганцовський, О. А., 2019. Корпоративна соціальна видовідальність: новаторство, ініціативізм, конкурентноспроможність. Запоріжжя, ЗНУ "Молода наука". 388.

12. Nikitenko Vitalina, Andriukaitiene Regina, Punchenko Oleg, 2019. Developing corporate management to improve the quality of customer service. HUMANITIES STUDIES: Collection of Scientific Papers. Zaporizhzhia: ZNU. 2019. 1 (78). 140-153.

13. Максименюк М.Ю., Нікітенко В.О., 2016. Формування парадигми інформаційно-комунікативного суспільства як різновиду складної соціальної системи і взаємодії. Гуманітарний вісник Запорізької державної інженерної академї. 66. 266278.

14. Олексенко Р.І., Афанасьєва Л. В., Музя Є. М., Колева К., 2017. Міжкультурний діалог в контексті єднання України. Украӥнознавчий альманах. 21. 15-20.

15. Олексенко P.І., 2013. Глобальні проблеми філософії від Античності до сьогодення в дискурсі ринкових трансформацій. Придніпровські соціально-гуманітарні читання: у 6-ти частинах. Ч. 2: матеріали Дніпропетровської сесії I I Всеукр. наук.практ. конф. з міжнародною участю. 148-150.

16. Пожуєв В. І. Осмислення місця і ролі інформації у сучасному суспільстві Гуманітарний вісник Запорізької державної інженерної академії. 2010. 42. 4-13. 
17. Попов С. М., 2010. Наукова парадигма суб'єкт-суб'єктного управління в умовах сучасного континууму. Гуманітарний вісник Запорізької державної інженерної академії. 2010. 43. 166-175.

18. Постол А. А., 2010. Постмодернізм як сучасна соціально-політична реальність. Гуманітарний вісник Запорізької держсвної інженерної академії. 42. 69-79.

19. Соснін О. В., Воронкова В. Г., Ажажа М. А., 2016. Філософія гуманістичного менеджменту (соціально-політичні, соціально-економічні, соціально-антропологічні виміри): навчальний посібник. Запоріжжя: Дике поле. 356.

20. Управління людськими ресурсами: філософські засади: навч. Посібник, 2006 / В. Г.Воронкова, А. Г.Беліченко, О. М.Попов та ін.К.: Професіонал, 576.

21. Рижова I.С., 2009. Становлення і розвиток дизайну як духовно-практичного феномена в інформаційно-культурному просторі, 2009. Гуманітарний вісник Запорізької державної інженерної академії. 36. 211-224.

22. Рижова I. С., 2009. Дизайн в технічних вузах, 2009. Гуманітарний вісник Запорізької державної інженерної академії. 37. 87-95.

23. Синяєва Л.В., Олексенко Р.І., Плаксіна І.М., 2007. Екологічні проблеми України та шляхи їх вирішення. Вісник Сумського національного аграрного університету. 4. 1215 .

24. Соснін О. В., Воронкова В. Г., Нікітенко В. О., Максименюк М. Ю., 2017. Інформаційно-комунікативний менеджмент: зарубіжний та вітчизняний досвід: навч. посіб. Київ: КПІ ім. Ігоря Сікорського.

25. Тараненко Г. Г., Олексенко Р. И., Молодыченко В. В., 2016. Аксиодуховная составляющая в становлении и гармонизации социо-культурного бытия человека. Гуманітарний вісник Запорізької державної інженерної академії: збірник наукових праць. 65. 27-40.

26. Череп А.В., Абліцова Т.С., 2009. Розвиток сучасного маркетингу та вимоги до нього. Вісник Хмельницького національного університету. №1. С.202-205.

27. Череп А.В., Лазнева I.O., 2005. Методи управління витратами виробництва продукції та їх порівняльний аналіз. Формування ринкових відносин в Україні, Вип.11. C.67-72

28. Voronkova Valentyna, Metelenko Natalya, Nikitenko Vitalina, Silina Iryna, 2019. System analysis of the economy of sustainable development as environmentally balnced and socially oriented one. HUMANITIES STUDIES: Collection of Scientific Papers. Zaporizhzhia: ZNU. 2019. 1 (78). 86-97.

29. Buhaichuk Oksana, 2019. Strategies of information and innovation activity development at enterprise in digital conditions. 1 (78). 75-85. HUMANITIES STUDIES: Collection of Scientific Papers. Zaporizhzhia: ZNU.

30. Zhuravel Kristina, 2019. Concept of flexible management at enterprise in digitalization and lean production conditions. HUMANITIES STUDIES: Collection of Scientific Papers. Zaporizhzhia: ZNU. 1 (78). 98-107.

31. Фурсін О. О., 2012. Механізми соціально-орієнтованого державного управління. Автореферат кандидатської дисертації 3 спеціальності «Механізми державного управління»: 25.00. 02. Харків.

32. Фурсін О. О., 2012. Шляхи і напрями удосконалення механізмів соціальноорієнтованого державного управління на рівні регіону // Гуманітарний вісник Запорізької державної інженерної академії. 48. 172-188.

\section{REFERENCES}

1. Azhazha M. A., 2012. Monitorynh yak instrument zabezpechennia yakosti derzhavnykh ta munitsypalnykh posluh. Humanitarnyi visnyk Zaporizkoi derzhavnoi inzhenernoi akademii. 50. 270-277.

The impact of digitalization and gadgetization on the development of corporate social responsibility in the evolution conditions from globalization to regionalization 
2. Azhazha M. A., 2006. Teoretyko-medolohichni zasady kontseptsii liudskoho kapitalu. Efektyvnist suchasnoho menedzhmentu orhanizatsii: zb. nauk. prats. Kh.: KhIMB. 267-271.

3. Regina Andriukaitiene, Valentyna Voronkova, Olga Kyvliuk, Marina Maksimenyuk, Aita Sakun, 2017. Theoretical insights into expression of leadership competencies in the process of management. Problems and Perspectives in Management. 15 (1-1). 220-226.

4. Cappel, O. L., 2004. Globalizacia. Ukrainska diplomatuchna enciklopedia. Kyiv. 706.

5. Voronkova, V. H., 2008. Globalizacia yak process yniversalizaciy stosynkiv mij derjavoy ta runkom. GumanItarniy visnik ZaporIzkoyi derzhavnoyi Inzhenernoyi akademiyi. Zaporizhzhia: ZDIA 35. 15-35.

6. Winck, B., 2020. JPMorgam officially forecasts a coronavirus-driven recession will rock the US and Europe by July. Available at: https://markets.businessinsider.com/news/stocks/coronavirus-fuel-recession-forecast-useurope-economic-july-market-jpmorgan-2020-3-1028994637/ (accessed 16 April 2020).

7. Andriukaitienè, R., Žukauskas, P. \& Vveinhardt, J., 2018. Management Culture and Corporate Social Responsibility, London: IntechOpen. 66-67.

8. Fishuk V., Matushko V. \& Chernev E. ta in., 2018. Ukraina 2030E-Kraina iz rozvunytoy cifrovoy ekonomikoy.

Available at: https://strategy.uifuture.org/kraina-z-rozvinutoyu-cifrovoyuekonomikoyu.html (accessed 16 April 2020).

9. Petrov, A. \& Ivanin, A., 2017. Spasenie v cifre. Cifrovizacia osnovnoi front mirovoi konkyrencii” Available at: https://finval.ru/about/articles/spasenie-v-tsifre-tsifrovizatsiyaosnovnoy-front-mirovoy-konkurentsii-/ (accessed 16 April 2020).

10. Kramer, M., 2020. Coronavirus is putting corporate social responsibility to the test. Available at: https://hbr.org/2020/04/coronavirus-is-putting-corporate-social-responsibility-tothe-test (accessed 16 April 2020).

11. Hantsovskyi, O. A., 2019. Korporatuvna social'na vidpovidalnist': innovaciynist, iniciativnist', konkyrentnospromojnost". Zaporizhzhia, Moloda nauka ZNU. 2019. 388.

12. Nikitenko Vitalina, Andriukaitiene Regina, Punchenko Oleg, 2019. Developing corporate management to improve the quality of customer service. HUMANITIES STUDIES: Collection of Scientific Papers. Zaporizhzhia: ZNU. 1 (78). 140-153.

13. Maksymeniuk M.Yu., Nikitenko V.O., 2016. Formuvannia paradyhmy informatsiinokomunikatyvnoho suspilstva yak riznovydu skladnoi sotsialnoi systemy i vzaiemodii. Humanitarnyi visnyk Zaporizkoi derzhavnoi inzhenernoi akademii. 66. 266-278.

14. Oleksenko R.I., Afanasieva L. V., Muzia Ye. M., Koleva K., 2017. Mizhkulturnyi dialoh v konteksti yednannia Ukrainy. Ukrainoznavchyi almanakh. 21. 15-20.

15. Oleksenko R.I., 2013. Hlobalni problemy filosofii vid Antychnosti do sohodennia v dyskursi rynkovykh transformatsii. Prydniprovski sotsialno-humanitarni chytannia: u 6-ty chastynakh. Ch. 2: materialy Dnipropetrovskoi sesii I I Vseukr. nauk.-prakt. konf. z mizhnarodnoiu uchastiu. 148-150.

16. Pozhuev, V. I., 2010. Osmislennya mistsya i roli informatsiyi u suchasnomu suspIlstvi. GumanItarniy visnik ZaporIzkoyi derzhavnoyi Inzhenernoyi akademiyi. 42 4-13.

17. Popov, S. M., 2010. Naukova paradigma sub'Ekt-sub'Ektnogo upravlInnya v umovah suchasnogo kontinuumu. GumanItarniy vIsnik Zaporizkoyi derzhavnoyi Inzhenernoyi akademiyi. 43. 166-175.

18. Postol, A. A., 2010. PostmodernIzm yak suchasna sotsIalno-polItichna realnIst. GumanItarniy vIsnik ZaporIzkoyi derzhavnoyi Inzhenernoyi akademiyi. 42. 69-79.

19. Publichne upravlinnia ta administruvannia $\mathrm{v}$ umovakh informatsiinoho suspilstva: vitchyznianyi i zarubizhnyi dosvid [Elektronnyi resurs] : monohrafiia, 2017 / red. S. Chernov, V. Voronkova, V. Banakh, ta in. ; ZDIA. Zaporizhzhia : ZDIA. 603. ISBN 978-617-685-027419.

20. Sosnin, O. V., Voronkova, V. H. \& Azhazha, M. A., 2016. Filosofiya 
gumanIstichnogo menedzhmentu (sotsIalno-politichni, sotsialno-ekonomichni, sotsialnoantropologichni vimiri): navchalniy posIbnik. ZaporIzhzhya: Dike pole. 356

20. Upravlinnya lyudskimi resursami: filosofski zasadi: navch. Posibnik, 2006 / V. H. Voronkova, A. G. Belichenko, O. M. Popov ta in. K. : Profesional 576.

21. Rizhova, I. S., 2009. Stanovlennya i rozvitok dizaynu yak duhovno-praktichnogo fenomena $\mathrm{v}$ informatsIyno-kulturnomu prostorI. GumanItarniy vIsnik ZaporIzkoyi derzhavnoyi snzhenernoyi akademiyi. 36. 211-224.

22. Rizhova, I. S., 2009. Dizayn v tehnIchnih vuzah. Gumanitarniy visnik Zaporizkoyi derzhavnoyi Inzhenernoyi akademiyi. 37. 87-95.

23. Syniaieva L.V., Oleksenko R.I., Plaksina I.M., 2007. Ekolohichni problemy Ukrainy ta shliakhy yikh vyrishennia. Visnyk Sumskoho natsionalnoho ahrarnoho universytetu. 4. 1215.

24. Sosnin O. V., Voronkova V. H., Nikitenko V. O., Maksymeniuk M. Yu., 2017. Informatsiino-komunikatyvnyi menedzhment: zarubizhnyi ta vitchyznianyi dosvid: navch. posib. Kyiv: KPI im. Ihoria Sikorskoho.

25. Taranenko H. H., Oleksenko R. Y., Moloduchenko V. V., 2016. Aksyodukhovnaia sostavliaiushchaia $\mathrm{v}$ stanovlenyy y harmonyzatsyy sotsyo-kulturnoho bыtyia cheloveka. Humanitarnyi visnyk Zaporizkoi derzhavnoi inzhenernoi akademii: zbirnyk naukovykh prats. 65. 27-40.

26. Cherep, A. V. \& Ablitsova, T. S., 2009. Rozvitok suchasnogo marketingu ta vimogi do nogo. Visnik Hmelnitskogo natsionalnogo universitetu.1. 202-205.

27. Cherep, A. V. \& Lazneva, I. O., 2005. Metodi upravlInnya vitratami virobnitstva produktssyi ta yih porivnyalniy analiz. Formuvannya rinkovih vidnosin v Ukrayini. 11. 67-72

28. Voronkova Valentyna, Metelenko Natalya, Nikitenko Vitalina, Silina Iryna, 2019. System analysis of the economy of sustainable development as environmentally balnced and socially oriented one. HUMANITIES STUDIES: Collection of Scientific Papers. Zaporizhzhia: ZNU. 1 (78). 86-97.

29. Buhaichuk Oksana, 2019. Strategies of information and innovation activity development at enterprise in digital conditions. HUMANITIES STUDIES: Collection of Scientific Papers. Zaporizhzhia: ZNU. 1 (78). 75-85.

30. Zhuravel Kristina, 2019. Concept of flexible management at enterprise in digitalization and lean production conditions. HUMANITIES STUDIES: Collection of Scientific Papers / Ed. V. Voronkova. Zaporizhzhia: ZNU. 1 (78). 98-107.

31. Fursin O. O., 2012. Mekhanizmy sotsialno-oriientovanoho derzhavnoho upravlinnia. Avtoreferat kandydatskoi dysertatsii z spetsialnosti «Mekhanizmy derzhavnoho upravlinnia»: 25.00. 02. Kharkiv.

32. Fursin O. O., 2012. Shliakhy i napriamy udoskonalennia mekhanizmiv sotsialnooriientovanoho derzhavnoho upravlinnia na rivni rehionu. Humanitarnyi visnyk Zaporizkoi derzhavnoi inzhenernoi akademii. 48. 172-188.

ГАНЦОВСЬКИЙ, О. А. - аспірант кафедри менеджменту організацій та управління проектами, Інженерний навчально-науковий інститут Запорізького національного університету (Запоріжжя, Україна)

E-mail: teck-t@yandex.ua,

ORCID iD: https://orcid.org/0000-0002-3418-7550

\section{ВПЛИВ ЦИФРОВІЗАЦІї ТА ГАДЖЕТИЗАЦІї НА РОЗВИТОК КОРПОРАТИВНОЇ СОЦІАЛЬНОЇ ВІДПОВІДАЛЬНОСТІ В УМОВАХ ЕВОЛЮЦІї ВІД ГЛОБАЛІЗАЦІї ДО РЕГІОНАЛІЗАЦІї}

The impact of digitalization and gadgetization on the development of corporate social responsibility in the evolution conditions from globalization to regionalization 


\section{Анотація}

У статті висвітлена сутність формування концепції корпоративної соціальної відповідальності (КСВ) у контексті розвитку глобальних тенденцій сучасного світу.

Актуальність дослідження пов'язана 3 тим, що характеристики мають черти Четвертої промислової революції та трансформацію глобальних тенденцій від уніфікаційних інтеграційних процесів до диверсифікованих структурних течій. Зіставлена необхідність втілення принципів регіоналізації та локального протекціонізму, на разі із інноваційною необхідністю інтеграції із концепціями гаджетизації та цифровізації. Співвідношення діяльності корпоративної соціальної відповідальності на ринку із трансформаційними змінами світу в умовах сучасної кризи.

Мета статті - сфокусовано дослідити категоріальні та понятійніособливості принципів становлення діяльності КСВ в умовах сучасних глобальних тенденцій світу. Розглянути та розкрити унікальну умовність формування концепції корпоративної соціальної відповідальності на принципах регіоналізації та локального протекціонізму.

Новизна та результати дослідження показують, що зосередженість на розвитку лише технологій $є$ обмежена. Важливість розкриття впливу технологій на добробут людей, світовий прогрес, розширення можливостей науки i людини, a саме впровадження концепції корпоративної соціальної відповідальності із своїми принципами та нормами на всіх рівнях господарювання, забезпечить втілення спільних цінностей, гнучких форм управління та взаємодію із новими технологіями Четвертої промислової революції 4.0, разом із осмисленням проривів у цифрових технологіях та адаптацією до їхніх впливів.

Ключові слова: корпоративна соціальна відповідальність, гаджетизація, цифровізація, регіоналізація, глобалізація, четверта промислова революція.

ГАНЦОВСКИЙ, А. А. - аспирант, факультет экономики и управления, Инженерний учебно-нгаучный институт Запорожского национального университета (Запорожье, Украина)

аспирант, факультет экономики и управления, Инженерний институт Запорожского национального университета

E-mail: teck-t@yandex.ua,

ORCID iD: https://orcid.org/0000-0002-3418-7550

\section{ВЛИЯНИЕ ЦИФРОВИЗАЦИИ И ГАДЖЕТИЗАЦИИ НА РАЗВИТИЕ КОРПОРАТИВНОЙ СОЦИАЛЬНОЙ ОТВЕТСТВЕННОСТИ В УСЛОВИЯХ ЭВОЛЮЦИИ ОТ ГЛОБАЛИЗАЦИИ К РЕГИОНАЛИЗАЦИИ}

Анотация

В статье освещена сущность формирования концепции корпоративной социальной ответственности (КСО) в контексте развития глобальных тенденций современного мира.

Актуальность исследования связаные с тем, что характеристики имеют черты Четвертой промышленной революции и трансформацию глобальных тенденций от унификационных интеграционных процессов в диверсифицированные структурные направления. Сопоставлена необходимость воплощения принципов регионализации и локального протекционизма $\mathrm{c}$ инновационной необходимостью интеграции с концепциями гаджетизации и цифровизации в текущем состоянии современного мира. 
Рассмотрено соотношение деятельности корпоративной социальной ответственности на рынке с трансформационными изменение мира в условиях современного кризиса.

Цель статьи - исследовать понятийные и категориальные особенности, принципы становления деятельности КСО в условиях современных глобальных тенденций бизнеса. Рассмотреть и раскрыть уникальную условность формирования концепции корпоративной социальной ответственности на принципах регионализации и локального протекционизма.

Новизна и результаты исследования показывают, что сосредоточенность на развитии только технологий является ограниченным. Важно раскрыть влияние технологий на благо людей, мировой прогресс, расширение возможностей науки и человека. Именно внедрение концепции корпоративной социальной ответственности со своими принципами и нормами на всех уровнях хозяйствования обеспечит воплощение общих, гибких форм управления совместно с новыми технологиями Четвертой промышленной революции 4.0, с осмыслением прорывов в цифровых технологиях и адаптацией к их воздействиям.

Ключевые слова: корпоративная социальная ответственность, гаджетизация, цифровизация, регионализация, глобализация, четвертая промышленная революция.

The impact of digitalization and gadgetization on the development of corporate social responsibility in the evolution conditions from globalization to regionalization 